\title{
"To call myself beloved, to feel myself beloved on the earth"-A Tribute to our Founding Editor Dick Bakemeier
}

\author{
Joseph F. O'Donnell
}

Published online: 22 April 2010

(C) Springer 2010

\author{
LATE FRAGMENT \\ And did you get what \\ you wanted from this life, even so? \\ I did. \\ And what did you want? \\ To call myself beloved, to feel myself \\ beloved on the earth.
}

I have always loved this poem by Raymond Carver; and when I read it and contemplate it, I think of Dick Bakemeier (Fig. 1). He is certainly beloved on this earth and has done so much for so many.

I always think of Margaret Edwards as the mother of cancer education. She had such great impact running the cancer education program at the National Cancer Institute, which spawned the interest of so many. If she is the mother, she had accomplices by her side, and there is none that I can think of that had as much impact as Dick Bakemeierand so I am declaring him the father of cancer education.

When I gave tribute to him when he bequeathed me the editorship of Journal of Cancer Education, I wrote a loving article about Dick called "On the Shoulders of a Giant." [1]. $\mathrm{He}$ is a giant and we all stand on his broad shoulders. I said that he had taken our journal from conception, to birth, infancy, childhood, and adolescence and we were poised to grow into a productive adulthood (entering Erik Erikson's stage of generativity-having as our major purpose giving to others).

I remarked at that time how I (and so many others who came to cancer medicine) was first attracted by Dick's

\section{J. F. O’Donnell ( $₫)$}

Dartmouth Medical School,

HB 7010,

Hanover, NH 03755, USA

e-mail: joseph.f.odonnell@dartmouth.edu

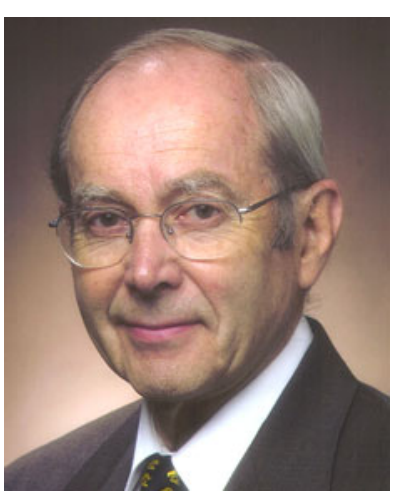

Fig. 1 Richard F Bakemeier, MD

Orange Book. He captured our interests as he and his colleagues laid out the beautiful evolving science and the disciplined approach to staging, deciding on treatment options, and, most of all, the total care of the patient and the family. Little did I know then that Dick, Margaret Edwards, and others were making the rounds of medical and dental schools to get them all to beef up and coordinate their cancer education programs. Dick led two very elegant and enormously impactful national surveys of cancer education in US schools that laid the foundation for where we are today. He was a stickler for good educational methodology including his insistence on specific and measurable aims, content, and processes that helped students learned and evaluation systems that made sure they did.

About 25 years ago, he founded this journal and through his tireless hard work and insistence on quality (and labors of love), the journal grew. I have to acknowledge the wonderful partnership with his wife Alice that helped the journal flourish. I count Dick and Alice (as 
so many others have) among my most treasured mentors and (s)heroes.

He turned the journal over to me...but I stand on his shoulders. It is a great view! The future looks bright and this journal WILL make a difference in cancer medicine.

The whole year of this 25 th edition is dedicated to Dick (and Alice). Deputy Editor Dick Gallagher has organized the tribute that follows. Read it with joy - think about Dick Bakemeier and all he has done for all of us!

We will be doing two new things: each year we will invite the Richard F. Bakemeier Review of an important topic in cancer education and each year the most cited paper will be awarded the Richard F. Bakemeier Prize. I have also asked Dick to write an editorial for one of the next issues about his thoughts on directions in which we should go with cancer education and the journal. His wisdom is always valuable!

Meanwhile - thanks, father of cancer education-we owe you a lot, perhaps even the turn in the death rate for cancer through the efforts of the people you have spawned into cancer education. Most of all, we owe you friendship and mentorship. You are beloved on this earth!

\section{References}

1. On the shoulders of a giant (2005) JCE, 20(4): 203-204 